Jurnal Health Sains: p-ISSN : 2723-4339 e-ISSN : 2548-1398

Vol. 2, No. 2, Februari 2021

\title{
PENGARUH INTERVENSI RAFIQ AL WILADA TERHADAP KECEMASAN SAAT PROSES BERSALIN PADA IBU PRIMIGRAVIDA DI RSIA ASRI PURWAKARTA
}

\begin{tabular}{l}
\hline ARTIKEL INFO \\
\hline Tanggal diterima: 5 Februari \\
2021 \\
Tanggal revisi: 15 Februari \\
2021 \\
Tanggal yang diterima: 25 \\
Februari 2021 \\
\hline Keywords: \\
Primigravida; rafiq al wilada; \\
third trimester
\end{tabular}

ABSTRACT

The purpose of this study was to find out the comparison of anxiety levels before and after intervention during the third trimester pregnancy until after the maternity process in primigravida mothers at RSIA Asri Purwakarta. PreExperimental method with one group pretest and posttest design. The study subjects were pregnant women in the third trimester until after the maternity process, while the intervention subjects were the entire study subjects and husbands. Sampling techniques with consecutive sampling. Number of samples $25 \quad(n=25)$. Data collection was conducted from June to August 2019. Measurement of anxiety using hrs-A questionnaire that has been developed by Hawari for pregnant women's anxiety. Test results validity $p<0.05$ and reliability 0.06 . Analyze the data, using Wilcoxon. Results showed that anxiety levels before intervention mostly experienced severe anxiety as much as 20 people (80\%) with a score score of $28-41$ while after intervention most experienced moderate anxiety as many as 11 people (44\%) with scores of 21-27 and mild anxiety of 10 people (40\%) with a score of 14-20. The average anxiety score before intervention was 33.08 (SD 5.992) and after intervention 22.76 (SD 4.737), indicating a decrease in anxiety score of 10.2 (95\% IK 8-12). There was a significant difference in average anxiety levels before and after intervention with a $p$ value of 0.001. Therefore, the intervention of rafiq al wilada can be used as an alternative intervention to prevent and overcome anxiety in pregnant women until after the maternity process. Conclusion There is a significant influence of intervention rafiq al wilada on the decrease in anxiety during the maternity process in primigravida mothers with a $p$ value of 0.001. Advice intervention rafiq al wilada can be used as an alternative intervention to prevent and overcome anxiety in pregnant women until the time of maternity.

\section{ABSTRAK}

Tujuan penelitian ini untuk mengetahui perbandingan tingkat kecemasan sebelum dan setelah intervensi rafiq al wilada saat kehamilan trimester tiga sampai setelah proses bersalin pada ibu primigravida di RSIA Asri Purwakarta. Metode yang di gunakan Pre-Experimental dengan one group pretest and posttest design. Subjek penelitian adalah ibu hamil trimester tiga hingga setelah proses bersalin, sedangkan subjek intervensi adalah seluruh subjek penelitian dan suami. Teknik pengambilan sampel dengan consecutive sampling. 
Jumlah sampel $25(\mathrm{n}=25)$. Pengambilan data dilakukan bulan Juni hingga Agustus 2019. Pengukuran kecemasan dengan menggunakan kuisioner HRS-A yang telah dikembangkan oleh Hawari untuk kecemasan ibu hamil. Hasil uji validitas $\mathrm{p}<0,05$ dan reliabilitas 0,06 . Analisa data, menggunakan Wilcoxon. Hasil menunjukkan bahwa tingkat kecemasan sebelum intervensi sebagian besar mengalami kecemasan berat sebanyak 20 orang (80\%) dengan skor nilai $28-41$ sedangkan setelah dilakukan intervensi sebagian besar mengalami kecemasan sedang sebanyak 11 orang (44\%) dengan skor 21-27 dan kecemasan ringan 10 orang (40\%) dengan skor 14-20. Rata-rata skor kecemasan sebelum intervensi 33,08 (SD 5,992) dan setelah intervensi 22.76 (SD 4,737), menunjukan adanya penurunan skor kecemasan sebesar 10,2 (95\% IK 8-12). Terdapat perbedaan signifikan rerata tingkat kecemasan sebelum dan setelah intervensi dengan nilai $p$ value 0,001 . Oleh karena itu intervensi rafiq al wilada dapat dijadikan sebagai alternatif intervensi untuk mencegah dan mengatasi kecemasan pada ibu hamil hingga setelah proses bersalin. Kesimpulan Terdapat pengaruh signifikan intervensi rafiq al wilada terhadap penurunan kecemasan saat proses bersalin pada ibu primigravida dengan nilai $p$ value 0,001 . Saran intervensi rafiq al wilada dapat dijadikan sebagai alternatif intervensi untuk mencegah dan mengatasi kecemasan pada ibu hamil hingga saat proses bersalin.

Coresponden Author:

Email: geuisanggi@gmail.com Artikel dengan akses terbuka dibawah lisensi

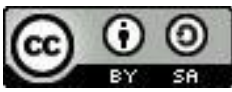

\section{Pendahuluan}

Depresi postpartum di Indonesia dari tahun ke tahun terus meningkat hal ini sesuai dengan data dari Depkes RI tahun 2014 yang mengatakan bahwa angka kejadian depresi post partum terjadi pada 1 sampai 2 per 1000 kelahiran atau $11 \%$ sampai dengan $15 \%$, sedangkan berdasarkan hasil penelitian yang dilakukan oleh RSUD dr. Soetomo Surabaya dan RSUD dr. Adam Malik Medan angka kejadian depresi postpartum yang disebabkan oleh kecemasan yang tidak ditangani dengan baik dari tahun 2010 hingga saat ini kejadiannya semakin meningkat yaitu sekitar $50 \%$ sampai $60 \%$ saat mereka memiliki anak pertama, sedangkan berdasarkan data dari
DINKES Purwakarta, dari tahun 2012 sampai dengan 2017 terdapat 5\% sampai 10\%. Oleh karena itu meskipun kecemasan merupakan hal yang wajar terjadi namun ketika kecemasan tersebut tidak teratasi maka dapat berdampak buruk sehingga diperlukan adanya intervensi untuk mencegah, mengatasi dan menurunkan kecemasan.

Intervensi yang dapat digunakan untuk mengurangi kecemasan berdasarkan beberapa hasil penelitian yang dilakukan didalam maupun di luar negeri pada trimester tiga hingga menjelang persalinan dan dinilai efektif, digolongkan menjadi dua metode yaitu intervensi farmakologi dan intervensi non farmakologi (Bakshi et al., 2008). Intervensi 
farmakologi digunakan untuk ibu yang mengalami kecemasan berat, berlangsung terus menerus, mengganggu aktifitas, tidak bisa tidur dan tidak bisa mengontrol emosi. Obat yang di gunakan adalah golongan obat penenang, obat anti-depresi, zapiron, dan obat tipe beta-blocker (Dixon et al., 2011). Sedangkan untuk intervensi non farmakologi digunakan pada ibu yang mengalami kecemasan sedang sampai dengan ringan (Bakshi et al., 2008). Intervensi non farmakologi yang sering digunakan adalah pijat, latihan nafas, dukungan sosial, dzikir, kompres hangat, aromaterapi, dan terapi music (Fauziah \& Agamuthu, 2012). Pada penelitian sebelum-sebelumnya intervensi tersebut dinilai efektif dan dapat digunakan untuk mencegah, mengatasi dan menurunkan kecemasan. Pada penelitian ini dipilih tiga jenis intervensi yaitu pijat, latihan nafas dan dukungan sosial dari suami karena intervensi tersebut mudah untuk dilakukan, murah, tidak menimbulkan efek samping, dapat dilakukan dimana dan kapan saja, dapat dilakukan oleh semua orang dengan diberikan pelatihan, sudah ada sejak dulu sehingga sangat dikenal semua lapisan masyarakat. Ketiga jenis intervensi tersebut di beri nama intervensi Rafiq al wilada.

Rafiq al wilada ambil dari bahasa Arab yang artinya adalah pendamping untuk proses persalinan (Kamus Besar Bahasa Indonesia, 2019). Secara harfiah Intervensi rafiq al wilada ini merupakan bentuk dukungan dari pendamping baik dari fisik, psikologi, sosio dan spiritual. Ketiga intervensi ini dipilih karena banyaknya keuntungan yang bisa didapatkan, mudah dan tidak memerlukan biaya. Intervensi rafiq al wilada diberikan melalui program pelatihan secara bersamaan antara suami dan istri, diberikan dalam bentuk pengetahuan dan keterampilan melalui ceramah tanya jawab, pemutaran video dan praktek bertujuan untuk meningkatkan pengetahuan dan juga keterampilan.
Intervensi rafiq al wilada itu sendiri merupakan penerapan dari peran dan tanggungjawab suami pada istri selama fase maternal yang diadopsi dari (Danaei et al., 2014) yaitu membantu memenuhi kebutuhan dan pekerjaan ibu selama kehamilan dan persalinan, memberikan kasih sayang, meningkatkan kenyamanan ibu, menyediakan transfortasi, menyediakan dana untuk biaya konsultasi dan persalinan, menemani atau mendampingi pada saat konsultasi dan persalinan, menyediakan makanan yang bergizi, mengawasi, memelihara, menjaga, mengambil keputusan ketika diperlukan, menentukan alat kontrasepsi yang digunakan dan mengurus anak. Penerapan peran dan tanggungjawab suami tidak hanya untuk memenuhi kebutuhan fisik saja akan tetapi kebutuhan psikologisnya.

\section{Metode Penelitian}

Penelitian ini menggunakan rancangan penelitian kuantitatif yaitu metode Pre- Eksperimental dengan one groups pre-test and post-test design dengan tujuan untuk mengetahui perbandingan tingkat kecemasan sebelum dan setelah diberikan intervensi. Populasi dalam penelitian ini adalah keseluruhan ibu hamil sampai bersalin di RSIA ASRI Purwakarta. Jumlah sampel diambil berdasarkan perhitungan dengan menggunakan teknik concecutive Sampling (sampel berurutan) yaitu berjumlah $25(\mathrm{n}=25)$. Consecutive sampling ini dipilih karena merupakan jenis pengambilan sampling yang paling baik, caranya mudah dan sebagian besar penelitian menggunakan teknik ini untuk pemilihan subjeknya. (Hidayat et al., 2011). Proses pengumpulan data menggunakan kuisioner. Kuisioner yang di gunakan adalah kuisioner kecemasan HRS-A yang telah dikembangkan kedalam bentuk bahasa Indonesia oleh Prof. Dadang Hawari pada tahun 2010 dan dimodifikasi untuk fase maternal dengan terlebih dahulu dilakukan uji 
validitas dan reabilitas dengan nilai uji validitas $\mathrm{p}$ value 0,30 dan uji reliabilitas dengan $\mathrm{p}$ value 0.60 . Pengolahan data menggunakan program statistik komputer dan dianalisis dengan uji statistik. Anlisa data pada penelitian ini menggunakan Wilcoxon.

\section{Hasil Penelitian}

Hasil penelitian tingkat kecemasan sebelum dan setelah intervensi rafiq al wilada pada ibu primigravida di RSIA Asri Purwakarta dengan jumlah responden $(n)=25$

\begin{tabular}{cccccc} 
Tingkat Kecemasan Sebelum dan Setelah \\
Intervensi Rafiq al wilada Pada Ibu \\
Primigravida Di RSIA Asri Purwakarta \\
(n=25) \\
\hline Variabel & Kategorik & n & $\begin{array}{c}\text { Presen } \\
\text { tase } \\
(\%)\end{array}$ & n & $\begin{array}{c}\text { Presenta } \\
\text { se (\%) }\end{array}$ \\
\hline Kecemsan & $\begin{array}{l}\text { Tidak cemas } \\
\text { (tanpa gejala) }\end{array}$ & 0 & 0 & 1 & 4 \\
\hline $\begin{array}{l}\text { Cemas Ringan } \\
\text { (gejala ringan) }\end{array}$ & 1 & 4 & 10 & 40 \\
\hline $\begin{array}{l}\text { Cemas Sedang } \\
\text { (gejala sedang) }\end{array}$ & 2 & 8 & 11 & 44 \\
\hline $\begin{array}{l}\text { Cemas Berat } \\
\text { (gejala berat) }\end{array}$ & 20 & 80 & 3 & 12 \\
\hline $\begin{array}{l}\text { Berat sekali } \\
\text { (panik) }\end{array}$ & 2 & 8 & 0 & 0 \\
\hline
\end{tabular}

Berdasarkan tabel pada penelitian ini tingkat kecemasan pada ibu primigravida sebelum dilakukan intervensi rafiq al wilada di RSIA ASRI sebagian besar responden mengalami kecemasan berat yaitu sebanyak 20 orang $(80 \%)$, sebagian responden mengalami kecemasan berat sekali sebanyak 2 orang (8 $\%)$, sebagian mengalami kecemasan sedang sebanyak 2 orang (8\%) dan sebagian kecil responden mengalami kecemasan ringan yaitu sebanyak 1 orang (4\%). Sedangkan tingkat kecemasan setelah dilakukan intervensi rafiq al wilada sebagaian besar mengalami kecemasan sedang yaitu sebanyak 11 orang (44\%), kecemasan ringan sebanyak 10 orang $(40 \%)$, kecemasan berat 3 orang (12\%) dan tidak ada kecemasan 1 orang (4\%).

Sedangkan hasil analisa bivariat untuk mengetahui pengaruh intervensi rafiq al wilada terhadap kecemasan saat bersalin pada ibu primigravida di RSIA Asri Purwakarta dengan menggunakan uji Wilcoxon.

\begin{tabular}{|c|c|c|c|c|}
\hline \multicolumn{5}{|c|}{$\begin{array}{c}\text { Pengaruh Intervensi Rafiq } \\
\text { terhadap Kecemasan Pa } \\
\text { Primigravida }\end{array}$} \\
\hline Variabel & $n$ & $\begin{array}{c}\text { Median } \\
\text { (SB) }\end{array}$ & $\begin{array}{l}\text { Rata-rata } \\
\text { perbedaan } \\
\text { (SD) }\end{array}$ & $P$ \\
\hline $\begin{array}{l}\text { Kecemasan } \\
\text { sebelum }\end{array}$ & 25 & $\begin{array}{c}33(15- \\
43)\end{array}$ & $\begin{array}{c}33,08 \\
(5,992)\end{array}$ & 0,001 \\
\hline $\begin{array}{l}\text { Kecemasan } \\
\text { setelah }\end{array}$ & 25 & $\begin{array}{c}24(14- \\
32)\end{array}$ & $\begin{array}{c}22,76 \\
(4,737)\end{array}$ & \\
\hline
\end{tabular}

Keterangan: hasil uji dengan menggunakan Wilcoxon. SD (standar deviasi), SB (simpang baku)

Berdasarkan hasil penelitian menyajikan analisa uji Wilcoxon didapatkan data kecemasan sebelum intervensi dengan $\mathrm{n}=25$, median 33 , minimum 15 , maksimum 43 dan setelah intervensi $n=25$, median 24 , minimum 14, maksimum 32 dan selisih ratarata 10, 32 dengan nilai p-value $<0,001$ dengan tingkat kepercayaan $95 \%$ artinya adalah terdapat perbedaan tingkat kecemasan sebelum dan setelah dilakukan intervensi rafiq al wilada. Pengujian hipotesisnya adalah Ho diterima.

\section{Pembahasan}

Pada penelitian ini berdasarkan hasil analisa statistik dengan menggunakan uji data berpasangan lebih dari dua kelompok untuk kategorik dengan menggunakan analisa Wilcoxon maka di dapatkan nilai $\mathrm{p}<0,001$, artinya pada penelitian ini terdapat pengaruh yang bermakna antara intervensi rafiq al wilada terhadap kecemasan saat bersalin pada ibu primigravida. Hal ini sesuai dengan penelitian yang dilakukan oleh (Yuksel et al., 2017) yang menyatakan bahwa teknik pernafasan yang tepat pada saat persalinan sangat efektif menurunkan kecemasan yaitu dari kecemasan sedang menjadi kecemasan ringan dengan nilai $\mathrm{p}$ value 0.005 , Penelitian lainnya adalah penelitian yang dilakukan oleh (Arifin et al., 2015) dihasilkan bahwa terdapat hubungan yang signifikan antara dukungan keluarga terhadap kecemasan dengan nilai $\mathrm{p}$ 
0,009. Selain itu, penelitian (Primasnia, 2017) pada ibu primigravida yang didampingi suami tidak mengalami kecemasan 65,2\%, sedangkan yang tidak didampingi suami selama persalinan kala I sebagian besar mengalami kecemasan 78,3\% maka hasil uji chi-square 0,007 artinya terdapat pengaruh yang signifikan antara pendampingan suami terhadap tingkat kecemasan ibu primigravida dalam proses persalinan kala I.

Hasil penelitian lain mengenai pendampingan suami adalah penelitian yang dilakukan oleh (Primasnia, 2017) yang menyatakan bahwa 23 orang ibu primigravida yang didampingi oleh suami selama persalinan kala I, sebagian besar tidak mengalami kecemasan $(65,2 \%)$, dan yang mengalami kecemasan sebanyak $34,8 \%$, sedangkan dari 23 orang ibu primigravida yang tidak didampingi oleh suami selama kala I persalinan sebagian besar mengalami kecemasan, 78,3\%) dan ibu yang tidak mengalami kecemasan yaitu $21,7 \%$ dengan nilai $\mathrm{p}$ value 0,007 . Hal ini membuktikan bahwa ada hubungan yang signifikan antara intervensi dengan tingkat kecemasan ibu primigravida dalam menghadapi proses persalinan.

Kecemasan ini di pengaruhi oleh beberapa faktor seperti tingkat usia, pendidikan, dan pekerjaan pada penelitian ini didapatkan data bahwa karakteristik responden dalam penelitian ini terdiri dari usia, pekerjaan dan pendidikan. Distribusi usia dari 25 pasang responden yang diberikan intervensi rafiq al wilada menggunakan klasifikasi usia dari Departmen kesehatan (Lestari et al., 2020). Sebagian besar responden pada penelitian ini berada pada kategori usia dewasa awal (26-35 tahun). Karakteristik dewasa awal adalah minat yang makin mantap terhadap fungsifungsi intelek, egonya mencari kesempatan untuk bersatu dengan orang-orang lain dan dalam pengalaman-pengalaman baru, terbentuk identitas seksual yang tidak akan berubah lagi, egosentrisme (terlalu memusatkan perhatian pada diri sendiri) diganti dengan keseimbangan antara kepentingan diri sendiri dengan orang lain dan tumbuh "dinding" yang memisahkan diri pribadinya (private self) dan masyarakat umum (the public), dan penyesuaian diri terhadap pola-pola kehidupan baru dan harapan sosial baru (Motoyama et al., 2009). Orang dewasa awal diharapkan memainkan peran baru, seperti peran suami atau istri, orang tua, pencari nafkah dan mengembangkan sikap-sikap baru, keinginan dan nilai-nilai baru sesuai dengan tugas-tugas baru yang diemban. Sehingga dapat di simpulkan bahwa pada usia remaja akhir dan dewasa awal merupakan periode peralihan yang memerlukan adaptasi yang kuat untuk menjalani periode perkembangan selanjutnya.

Penyesuaian diri atau adaptasi pada periode dewasa awal menjadi periode yang khusus dan sulit dari rentang hidup seseorang. Apabila mereka menemui kesulitan-kesulitan yang sukar diatasi, mereka ragu ragu untuk meminta pertolongan dan nasehat orang lain, karena enggan dianggap "belum dewasa". Hal ini di dukung oleh penelitian sebelumnya yang dilakukan oleh (Rodríguez, 2012) yang menyebutkan bahwa usia ikut menentukan tingkat kecemasan, yaitu kecemasan sering terjadi pada golongan usia muda atau usia rentan dan penelitian dilakukan oleh (Pookulangara et al., 2013) semakin bertambah usia semakin baik tingkat kematangan emosi seseorang serta kemampuan dalam menghadapi berbagai persoalan. Oleh karena itu pada usia dewasa awal diperlukan adanya suatu arahan, bimbingan dan pendampingan agar mencapai kedewasaan yang baik.

Kecemasan yang tidak teratasi juga merupakan prediktor terjadinya nyeri selama melahirkan yang akan mempengaruhi kesehatan ibu dan bayi. Sebaliknya nyeri selama melahirkan juga menyebabkan 
timbulnya kecemasan, sehingga antara stres, kecemasan, ketakutan dan nyeri merupakan siklus yang berkesinambungan. Sementara pasien yang mengalami nyeri empat kali lebih cemas dibandingkan dengan pasien yang tidak mengalami nyeri.

Selain itu kecemasan dapat berdampak pada kesehatan fisik dan mental baik janin maupun ibunya. Misalnya terhambatnya perkembangan dan pertumbuhan janin, rendahnya skor Apgar, dan meningkatnya kejadian post partum blues. Adapun tanda dan gejala kecemasan menurut (Sundari et al., 2010) yang bersifat fisik diantaranya adalah: jari tangan dingin, detak jantung makin cepat, berkeringat dingin, kepala pusing, nafsu makan berkurang, tidur tidak nyenyak, dada sesak. Gejala yang bersifat mental adalah: ketakutan ditimpa bahaya, tidak dapat memusatkan perhatian, tidak tenteram, dan ingin lari dari kenyataan. Oleh karena itu perlu tindakan pencegahan dan intervensi untuk mengatasinya.

Kecemasan sebelum dilakukan intervensi rafiq al wilada pada penelitian ini sebagian besar berada pada kategori kecemasan berat. Hasil penelitian ini didukung oleh beberapa hasil penelitian yang dilakukan sebelumnya yaitu hasil penelitian yang dilakukan oleh (Bashari et al., 2018) dengan penelitiannya menggunakan intervensi massage endorphine; (Halimatussadiah et al., 2017) dengan menggunakan intervensi Back Efflurage Massage (BEM); (Yuksel et al., 2017) dengan menggunakan intervensi latihan nafas dan penelitian (Faruk et al., 2017) dengan intervensi dukungan suami, menyebutkan bahwa kecemasan sebelum dilakukan intervensi berada pada tingkatan atau kategori cemas berat. hal ini mungkin disebabkan karena adanya perasaan khawatir dan takut mengenai kondisi ibu dan janin yang di kandungnya.

Kecemasan yang terjadi pada ibu hamil trimester tiga hingga melahirkan menurut (Varney et al., 2010) terjadi karena ketakutan dan kekhawatiran pada diri sendiri dan janin yang dikandungnya yang meliputi ketakutan akan kegawatan pada saat kehamilan dan persalinan, takut tidak dapat memenuhi kebutuhan janin yang dikandungnya, pengalaman trauma yang dirasakan orang lain, takut bayi yang dikandungnya meninggal, takut tidak dapat mengurus anak dan suaminya setelah persalinan, takut tidak dapat bersosialisasi dengan teman atau keluarga yang lain, dan takut tidak dapat mengurus kebutuhan dirinya sendiri. Ketakutan, kekhawatiran dan kecemasan ini jika dibiarkan terus terjadi mungkin dapat berdampak buruk baik bagi ibu maupun janin yang di kandungnya, oleh karena itu diperlukan suatu tindakan intervensi untuk mencegah dan mengatasinya. Intervensi untuk mencegah dan mengatasi kecemasan berdasarkan hasil penelitian yang dilakukan baik dalam maupun luar negeri dapat dilakukan baik secara farmakologi maupun non farmakologi (Bakshi et al., 2008). Kecemasan setelah persalinan dapat berkurang namun ada juga yang malah semakin bertambah tergantung pada kemampuan adaptasi dan koping dari individu serta adanya faktor eksternl ataupun pengaruh dari yang lain (Hawari \& Heeks, 2010). Faktor yang dapat menyebabkan kecemasan setelah persalian berbeda dengan pada saat kehamilan dan juga persalian, oleh karena itu diperlukan peningkatan pengetahuan dan kemampuan agar dapat beradaptasi dengan baik.

Sedangkan hasil penelitian setelah dilakukan intervensi rafiq al wilada, pada penelitian ini tingkat kecemasan sebagian besar responden adalah kecemasan sedang. Penelitian ini sesuai dengan hasil penelitian sebelumnya (Bashari et al., 2018); (Halimatussadiah et al., 2017) dengan menggunakan intervensi Back Efflurage Massage (BEM); (Yuksel et al., 2017) dan (Faruk et al., 2017) yang menyebutkan bahwa kecemasan setelah dilakukan intervensi berada pada kategori sedang hingga ringan. 
Penurunan tingkat kecemasan ini terjadi setelah diadakannya pelatihan mengenai intervensi rafiq al wilada. Intervensi yang digunakan pada penelitian ini adalah intervensi rafiq al wilada. Intervensi rafiq al wilada ini dilakukan oleh suami sehingga hubungan lebih intim, istri merasa lebih nyaman, merasa di perhatikan karena kedekatan lebih erat, kasih sayang lebih besar, rasa cinta terhadap istri meningkat, suami lebih menghargai perjuangan dan pengorbanan istri, suami merasa lebih bertanggungjawab baik secara fisik maupun psikologis ibu, pengetahuan suami mengenai perannya sebagai suami dan bapak lebih meningkat dan siap dan mereka menganggap biaya yang dikeluarkan lebih hemat karena intervensi dilakukan oleh suami, kelahiran menjadi lebih cepat dan resiko kegawatan dapat di minimalkan.

Selain itu intervensi rafiq al wilada terdiri dari tiga jenis intervensi yaitu pijat, latihan nafas dan dukungan suami. Ketiga jenis intervensi tersebut dilakukan secara bersama dan oleh satu orang. Subjek penelitian tidak diperlakukan sebagai objek. Berdasarkan penelitian sebelumnya, ketiga jenis intervensi tersebut efektif untuk menurunkan dan mengatasi kecemasan. Hal ini sesuai dengan hasil penelitian (Bashari et al., 2018); (Halimatussadiah et al., 2017) dengan menggunakan intervensi Back Efflurage Massage (BEM); (Yuksel et al., 2017) dan (Faruk et al., 2017) yang menyebutkan bahwa terjadi penurunan tingkat kecemasan dari kecemasan berat sebelum dilakukan intervensi menjadi kecemasan ringan setelah dilakukan intervensi.

Pijat punggung merupakan salah satu tindakan alternatif dan terapi komplementer, terapi sentuhan yang digunakan untuk mengurangi nyeri, cemas, takikardia, dan hipertensi pada pasien beberapa tahun terakhir ini. Pijat punggung bertujuan untuk membantu pengobatan sistem saraf dan kardiovaskular secara efektif menimbulkan rasa aman, rileks, dan rasa nyaman (Estri et al., 2016). Di Indonesia, pijat punggung dilakukan ketika perawat memandikan pasien dengan tirah baring untuk memberikan rasa nyaman.

Pijat merupakan salah satu cara memanjakan diri, karena sentuhan memiliki keajaiban tersendiri yang sangat berguna untuk menghilangkan rasa lelah pada tubuh, memperbaiki sirkulasi darah, merangsang tubuh untuk mengeluarkan racun serta meningkatkan kesehatan pikiran Selain itu pula, karena pijat punggung merangsang tubuh melepaskan senyawa endorphin yang merupakan pereda sakit alami. Endorphin juga dapat menciptakan rasa nyaman dan enak (Purnomo et al., 2017).

Pijat dan latihan nafas merupakan intervensi yang di gunakan untuk relaksasi. Pada saat pemijatan terjadi sentuhan pada otot dan juga pembuluh darah, sehingga dapat mengembalikan dan melenturkan otot dan memperlancar peredaran darah, ketika peredaran darah lancar maka pengangkutan oksigen dan juga hasil metabolisme ke otak menjadi lancar dan terpenuhi, sehingga hipotalamus akan berfungsi dengan baik dan mengeluarkan hormon endorphine secara alami (Kozier et al., 2012). Endorfin paling berkhasiat, kerjanya lima atau enam kali lebih kuat dibandingkan dengan obat bius.

Endorfin adalah polipeptida, yang mampu mengikat ke reseptor saraf di otak untuk memberikan bantuan dari rasa sakit yang di sekresi oleh kelenjar Hipofise. Endorphin merupakan hormon penghilang rasa sakit yang alami berkaitan dengan reseptor opioid dalam otak (Kozier et al., 2012). Peran penting dari endorfin adalah bekerja dengan reseptor obat penenang yang dikenal untuk meringankan rasa sakit secara umum. Endorphine dihasilkan di otak Anda, saraf tulang belakang, dan ujung saraf lainnya. Pada penelitian ini intervensi dilakukan dengan pendidikan dan pelatihan 
berkelanjutan oleh tenaga yang berkompeten dan bersertifikat. Pendidikan dan pelatiahn ini meliputi pemberian materi mengenai perubahan fisik dan psikologis ibu hamil dan bersalin, peran suami pada saat kehamilan dan persalinan, dan persalinan. Pemberian materi dilakukan dengan metode pembelajaran ceramah tanya jawab. Selain materi intervensi ini pun diberikan dalam bentuk menonton video, demo dan praktek untuk memijat punggung dan latihan nafas. Penayangan video selama 5-10 menit berupa tulisan, suara, gambar dan music pengiring. Setelah pemutaran video kemudian dilakukan demo oleh peneliti dan dua orang asisten peneliti terhadap 3 orang responden. Praktek mandiri dilaksanakan secara bergantian dan di pantau serta diajarkan lebih detail oleh peneliti dan asisten peneliti.

Materi dan video yang digunakan dalam penelitian ini sesuai dengan materi dan video yang diteliti. Responden dalam penelitian ini, sebagian besar memiliki pendidikan sekolah tingkat menengah (SMA/SMK). Menurut Stalker dan Elander (2015) bahwa materi dalam video dapat menambah informasi untuk meningkatkan tujuan yang diharapkan pada kelompok dengan pendidikan menengah, bahkan pendidikan yang lebih rendah. Video yang ditampilkan dalam penelitian ini menggunakan bahasa Indonesia, kata-kata mudah dimengerti dan dipahami oleh responden. Hal ini sama dengan yang dinyatakan oleh (Aronson et al., 2012); (Chen et al., 2019) bahwa media video lebih mudah diakses dalam hal bahasa, komunikasi, dan sering dikembangkan sebagai alternatif menyebar dengan cepat dan menjangkau populasi yang luas.

Pemberian materi dilakukan selama 15 menit dan untuk pemutaran video dilakukan selama 5-10 menit. Hal ini sejalan dengan hasil penelitian Pemutaran 1 kali video ini sama dengan penelitian dari (Aronson et al., 2012) di China bahwa intervensi video yang diberikan selama 15 menit saat responden berkunjung pada jadwal pemeriksaan kesehatannya di rumah sakit dan hasilnya pengetahuan responden terhadap vaksin varisela meningkat. Media yang diberikan baik materi, praktek maupun video melibatkan dua panca indera sekaligus yaitu penglihatan dan pendengaran. Dikatakan juga bahwa video dapat memberikan stimulus pada pendengaran dan penglihatan sehingga hasil yang diperoleh bisa maksimal (Silalahi et al., 2018).

Selain itu Menurut (Aronson et al., 2012) bahwa edukasi kesehatan yang berbasis video dapat meningkatkan keterlibatan responden, menghapus heterogenitas dan membuat responden memahami isi dari materi pendidikan dengan mudah karena dapat menghilangkan potensi inkonsistensi, dapat difahami dengan individu yang melek huruf yang lebih rendah. Hasil penelitian dari (Logsdon et al., 2015) memberikan dasar bahwa untuk metode pengajaran yang disukai dapat meningkatkan hasil dalam jangka panjang bagi ibu dan bayinya dan untuk menilai efektivitas biaya penyampaian informasi kesehatan menggunakan teknologi dan sangat menjanjikan untuk meningkatkan penyerapan informasi di antara ibu baru dengan keterampilan melek huruf yang terbatas, status kesehatan ibu dan bayi, dan kepuasan mereka dengan perawatan.

Dalam pemberian intervensi edukasi video terdapat proses penyimpanan memori yang lebih bertahan terhadap informasi yang disampaikan. Hal ini sesuai dengan penelitian yang dilakukan oleh (Wilson et al., 2010) meneliti pemberian edukasi dengan video di antara penderita asma, dan menunjukkan bahwa peserta dengan tingkat melek huruf yang lebih rendah yang menerima materi video mengingat lebih banyak informasi prosedural tentang penggunaan inhaler, dibandingkan dengan mereka yang menerima materi tertulis (leaflet/booklet). Jadi ketika peneliti menggunakan dua media sekaligus diharapkan dapat meningkatkan pengetahuan dan 
keterampilan dari ibu dan suaminya. Hal ini di tunjukkan dengan hasil penelitian ini. Sebelum diberikan intervensi sebagian besar responden belum mengetahui bagaimana cara mencegah dan mengatasi kecemasan serta mengetahui peran dan tanggung jawab suami dan setelah intervensi mereka dapat beradaptasi dan menggunakn koping positif sehingga terjadi penurunan kecemasan.

\section{Kesimpulan}

Berdasarkan hasil penelitian dan pembahasan, maka kesimpulan dalam penelitian ini adalah intervensi Rafiq al wilada dapat menurunkan kecemasan pada ibu primigravida saat bersalin. Kesimpulan khusus pada penelitian ini yaitu tingkat kecemasan sebelum dilakukan intervensi Rafiq al wilada pada penelitian ini sebagian besar mengalami kecemasan berat yaitu 20 orang atau $80 \%$ dengan nilai skor kecemasan 28- 41. Sedengkan tingkat kecemasan setelah dilakukan intervensi Rafiq al wilada pada penelitian ini terjadi penurunan dari kecemasan berat menjadi kecemasan sedang sebanyak 11 orang (44\%) dengan nilai skor 28 41 dan kecemasan ringan sebanyak 10 orang (40\%) dengan nilai skor kecemasan 21-27. Dan intervensi Rafiq al wilada secara signifikan berpengaruh terhadap penurunan kecemasan saat proses bersalin pada ibu primigravida di RSIA Asri Purwakarta dengan nilai $\mathrm{p}$ value $<0.001$.

\section{BIBILIOGRAFI}

Arifin, A., Kundre, R., \& Rompas, S. (2015). Hubungan Dukungan Keluarga Dengan Kecemasan Ibu Hamil Menghadapi Proses Persalinan Di Puskesmas Budilatama Kecamatan Gadung
Kabupaten Buol Propinsi Sulawesi Tengah. Jurnal Keperawatan, 3(2).

Aronson, I. D., Plass, J. L., \& Bania, T. C. (2012). Optimizing Educational Video Through Comparative Trials In Clinical Environments. Educational Technology Research And Development, 60(3), 469482.

Bakshi, S. R., Singh, V., Balani, K., Mccartney, D. G., Seal, S., \& Agarwal, A. (2008). Carbon Nanotube Reinforced Aluminum Composite Coating Via Cold Spraying. Surface And Coatings Technology, 202(21), 5162-5169.

Bashari, M. H., Usman, H. A., Azizah, D. W. N., Pramesti, D. A., Nurcahyani, A. K. S. D., Ilyasa, A. H., Zalia, N. D., Putra, R. D., Yuliani, L., \& Andini, D. (2018). Upaya Meningkatkan Deteksi Dini Kanker Payudara Di Smkn 1 Cijulang Kabupaten Pangandaran. Jurnal Pengabdian Pada Masyarakat, 3(2), 165-170.

Chen, Y., Chen, X.-Y., Du, H.-T., Zhang, X., Ma, Y.-M., Chen, J.-C., Ye, J.-W., Jiang, X.-R., \& Chen, G.-Q. (2019). Chromosome Engineering Of The Tca Cycle In Halomonas Bluephagenesis For Production Of Copolymers Of 3Hydroxybutyrate And 3Hydroxyvalerate (Phbv). Metabolic Engineering, 54, 69-82.

Danaei, G., Lu, Y., Singh, G. M., Carnahan, E., Stevens, G. A., Cowan, M. J., Farzadfar, F., Lin, J. K., Finucane, M. M., \& Rao, M. (2014). Cardiovascular Disease, Chronic Kidney Disease, And Diabetes Mortality Burden Of Cardiometabolic Risk Factors From 1980 To 2010: A Comparative Risk Assessment. Lancet Diabetes \& Endocrinology.

Dixon, J. B., Zimmet, P., Alberti, K. G., Rubino, F., \& Prevention, I. D. F. T. On E. And. (2011). Bariatric Surgery: An Idf Statement For Obese Type 2 Diabetes. Surgery For Obesity And Related 
Diseases, 7(4), 433-447.

Estri, A. K., Fatimah, S., \& Prawesti, A. (2016). Perbandingan Abdominal Massage Dengan Teknik Swedish Massage Dan Teknik Effleurage Terhadap Kejadian Konstipasi Pada Pasien Yang Terpasang Ventilasi Mekanik Di Icu. Jurnal Keperawatan Padjadjaran, 4(3).

Faruk, S. U., I Gede, A. S., Seno, G. A., Eddy, S., I Komang, A. W., Hardiman, M. S., I Ketut, S., Ni Kadek, K., Ehwan, K., \& Baskoro, S. B. (2017). Proceeding Seminar Nasional Seni Rupa Dan Desain: Penanda Sejarah Kebangsaan.

Fauziah, S. H., \& Agamuthu, P. (2012). Trends In Sustainable Landfilling In Malaysia, A Developing Country. Waste Management \& Research, 30(7), 656663.

Halimatussadiah, A., Resosudarmo, B. P., \& Widyawati, D. (2017). Social Capital To Induce A Contribution To Environmental Collective Action: Results From A Laboratory Experiment In Indonesia. International Journal of Environment And Sustainable Development, 16(4), 397-414.

Hawari, A., \& Heeks, R. (2010). Explaining Erp Failure In A Developing Country: A Jordanian Case Study. Journal of Enterprise Information Management.

Hidayat, Z., Babuska, R., De Schutter, B., \& Nunez, A. (2011). Observers For Linear Distributed-Parameter Systems: A Survey. 2011 Ieee International Symposium On Robotic And Sensors Environments (Rose), 166-171.

Kozier, B., Erb, G., Berman, A., \& Snyder, S. (2012). Stress Et Adaptation. B. Kozier, G.

Lestari, S. D., Leon, F. M., Widyastuti, S., Brabo, N. A., \& Putra, A. H. P. K. (2020). Antecedents And Consequences Of Innovation And Business Strategy On
Performance And Competitive Advantage Of Smes. The Journal of Asian Finance, Economics, And Business, 7(6), 365-378.

Logsdon, G. A., Barrey, E. J., Bassett, E. A., Denizio, J. E., Guo, L. Y., Panchenko, T., Dawicki-Mckenna, J. M., Heun, P., \& Black, B. E. (2015). Both Tails And The Centromere Targeting Domain Of CenpA Are Required For Centromere Establishment. Journal Of Cell Biology, 208(5), 521-531.

Motoyama, S., Sarai, M., Harigaya, H., Anno, H., Inoue, K., Hara, T., Naruse, H., Ishii, J., Hishida, H., \& Wong, N. D. (2009). Computed Tomographic Angiography Characteristics Of Atherosclerotic Plaques Subsequently Resulting In Acute Coronary Syndrome. Journal of The American College Of Cardiology, 54(1), 49-57.

Pookulangara, S. A., Kinley, T. R., Josiam, D. M., \& Spears, D. L. (2013). Hollywood And Fashion. Influence On Apparel Purchase Decisions. International Journal of Sales, Retailing And Marketing, 2(1), 50-63.

Primasnia, P. (2017). Hubungan Pendampingan Suami Dengan Tingkat Kecemasan Ibu Primigravida Dalam Menghadapi Proses Persalinan Kala I Di Rumah Bersalin Kota Ungaran. Prosiding Seminar Nasional \& Internasional.

Purnomo, A., Ratnawati, N., \& Aristin, N. F. (2017). Pengembangan Pembelajaran Blended Learning Pada Generasi Z. Jurnal Teori Dan Praksis Pembelajaran Ips, 1(1), 70-76.

Rodríguez, M. A. (2012). Inhibition Of Localized Corrosion In Chromium Containing Stainless Alloys. Corrosion Reviews, 30(1-2), 19-32.

Silalahi, V., Lismidiati, W., Hakimi, M., Keperawatan, B. I., Kedokteran, F., \& Mada, U. G. (2018). Efektivitas 
Audiovisual Dan Booklet Sebagai Media Edukasi Untuk Meningkatkan Perilaku

Skrining Iva Effectiveness Of Audiovisual And Booklet As Education Media To. J Media Kesehat Masy Indones, 14(3), 304â.

Sundari, S. S., Marimuthu, K., Sivraman, M., \& Babu, S. S. (2010). Composition Dependent Structural And Optical Properties Of Sm3+-Doped Sodium Borate And Sodium Fluoroborate Glasses. Journal of Luminescence, 130(7), 1313-1319.

Varney, C. N., Sun, K., Rigol, M., \& Galitski, V. (2010). Interaction Effects And Quantum Phase Transitions In Topological Insulators. Physical Review $B, 82(11), 115125$.

Wilson, E. A. H., Park, D. C., Curtis, L. M., Cameron, K. A., Clayman, M. L., Makoul, G., Vom Eigen, K., \& Wolf, M. S. (2010). Media And Memory: The Efficacy Of Video And Print Materials For Promoting Patient Education About Asthma. Patient Education And Counseling, 80(3), 393-398.

Yuksel, H., Cayir, Y., Kosan, Z., \& Tastan, K. (2017). Effectiveness Of Breathing Exercises During The Second Stage Of Labor On Labor Pain And Duration: A Randomized Controlled Trial. Journal Of Integrative Medicine, 15(6), 456-461. 